\title{
ASSESSMENT OF THE VALUE OF PROTECTED AREAS IN SERBIA, ON THE EXAMPLE OF APPLICATION OF PA-BAT METHOD AND TOURISM DEVELOPMENT
}

\author{
Milica Dobričić ${ }^{1}$ \\ Goran Sekulić
}

DOI: https://doi.org/10.31410/tmt.2020.285

\begin{abstract}
This chapter discusses the importance of evaluating ecosystem services by showcasing the Protected Areas Benefit Assessment Tool (PA-BAT), which has been applied in seven Dinaric Arc countries, and has gathered information on a range of values and benefits that protected areas provide. The PA-BAT results presented here include data for protected areas in Serbia (national parks Tara, Djerdap, Fruška gora and Kopaonik, Landscape of exceptional features of Vlasina and Special Nature Reserve of the Upper Danube) and economic assessment of 22 protected area values with special reference to tourism and recreation. This chapter gives a brief overview of other analyzes and initiatives for assessing the value of ecosystem services related to protected areas in Serbia. This chapter aims to contribute to a better understanding and promotion of the concept of ecosystem services in tourism and other sectors using PA-BAT and other methods of evaluation of protected area services.
\end{abstract}

Keywords: Protected Areas Benefit Assessment Tool (PA-BAT), Serbia, Ecosystem services, Tourism.

\section{INTRODUCTION}

$\mathrm{E}$ conomic assessment of the value of protected areas is of strategic importance for the local and national economy and especially for the development of tourism. Evaluation of protected areas and mapping of provided values, based on effective participation of decision makers and other stakeholders, are part of a long-term process that leads to greater interest for conservation and sustainable investments in natural values. Of particular importance is the involvement of various stakeholders in decision-making in natural resource management (Gbadegesin \& Ayileka, 2000; Rastogi et al., 2010; Lakićević, 2013; Dobričić \& Josimović, 2018), as well as the involvement of ecosystem services and the results of their evaluation in other sectoral areas, one of which is tourism (Zingstra et al., 2009; Stojkov \& Dobričić, 2012; Dobričić, 2012a; Woodruff \& Ben Dor, 2016; Dobričić et al., 2017). Ecosystem services are essentially the benefits that human society receives from nature (Millennium Ecosystem Assessment, 2005). Unfortunately, the population living in protected areas is often unaware of the benefits that ecosystem services bring to them, much less its economic value (Costanza, 1997). In order to overcome this problem, methods based on the participation of local communities are being developed, such as the Protected Areas Benefit Assessment Tool (PA-BAT). The development of tourism and its activities largely depends on ecosystem services (Pueyo-Ros, 2018), while the degradation and depletion of ecosystem services and resources over time can jeopardize the ecological sustainability of the tourism sector itself (Simmons, 2013).

To date, numerous evaluations of protected areas have been conducted (WWF, 2011; Spurgeon et al., 2009; UNDP, 2011; Flores \& Selimi, 2013; Flores \& Ivicic, 2011; Emerton, 2009; UNEP,

\footnotetext{
Ministry of Construction, Transport and Infrastructure, Belgrade, Serbia

World Wide Fund for Nature-WWF Adria, Belgrade, Serbia
} 
2016), which have improved our knowledge on natural values and have contributed to better management of protected areas. So far, several assessments of ecosystem values have been done in protected areas in Serbia such as the Special Nature Reserve Koviljsko-Petrovaradinski rit, Bosutske šume, Djerdap National Park or the Special Nature Reserve Zasavica. The overview of the results of those assessments is given in a separate part of this chapter. The evaluation of protected areas, through the evaluation of ecosystem services, also contributes to the implementation of the Strategic Plan for Biodiversity 2011-2020 and the achievement of Aichi goals by raising awareness of the value of biodiversity and by providing sustainable solutions for its use and conservation. (Secretariat of the Convention on Biological Diversity, 2010). In addition, ecosystem services have a significant role in achieving the global Sustainable development goals, especially goal 15 , which refers to the sustainable use of terrestrial ecosystems and stopping the loss of biodiversity (UN, 2015).

In this chapter, special attention is given to the application of protected areas benefit assessment tool (PA-BAT) for the assessment of the value of protected areas, i.e. the methodology developed by Dudley \& Stolton (2009). To date, the PA-BAT methodology has been applied to 58 protected nature areas in seven Dinaric Arc countries - Slovenia, Croatia, Bosnia and Herzegovina, Montenegro, Macedonia, Albania and Serbia (Ivanić, 2017; Ivanić et al., 2017; Sekulić et al., 2017; Sekulić et al., 2018). This chapter presents the results of the PA-BAT assessment conducted in six protected areas in Serbia (Tara, Djerdap, Fruška gora and Kopaonik National Parks, Vlasina Landscape of Outstanding Features and Special Nature Reserve Gornje Podunavlje), as well as the results of the economic assessment of 22 values of the protected areas, with special reference to tourism as one of the ecosystem values of protected areas. This chapter aims to contribute to a better understanding and promotion of the concept of ecosystem services in the development of tourism and other sectors by applying the PA-BAT methodology for the evaluation of protected areas.

\section{OVERVIEW OF THE VALUE ASSESSMENTS OF PROTECTED AREAS IN SERBIA}

So far, several assessments of the value of protected areas in Serbia have been conducted with different methodologies applied. The subjects of the assessment were the Djerdap National Park in 2014, the Koviljsko-Petrovaradinski rit Special Nature Reserve in 2015 and the Bosut-Morović forests in 2018. Assessments of the mentioned protected areas were conducted by the Institute for Nature Protection of Serbia and PE National Park Djerdap (for NP Djerdap), as well as the Provincial Institute for Nature Protection of Serbia (for SRP Koviljsko-Petrovaradinski rit and Bosutske šume).

The assessment of the Djerdap National Park identified all four common categories of ecosystem services (providing, regulating, cultural and supporting). Two dominant ecosystems have been identified in the park area - forest and aquatic (Javno preduzeće Nacionalni park Đerdap \& Zavod za zaštitu prirode Srbije, 2014). Great potential for development of specific types of tourism based on natural predispositions and values of the Djerdap area (nautical, ethno and ecotourism, hunting and fishing, excursion, historical, wine, gastronomic, geotourism, photo safaris, etc.) has been indicated. By reviewing the state of ecosystems and the ways and scope of using their services, it was concluded that the capacities of natural capital are still preserved and that they have the potential for development, primarily of local communities. Having in mind the present predominant types of ecosystem services and the type of economic and other activities in the subject area, interested groups and sectors have been identified that benefit from these resources 
and services, namely: economic sector (public, state and private companies), local governments (local communities and municipalities), non-governmental sector (non-governmental organizations, groups of citizens, local initiatives, etc.) and the international organizations and initiatives.

The evaluation of the Koviljsko-Petrovaradinski Rit Special Nature Reserve was conducted by the Provincial Institute for Nature Protection, Novi Sad, in 2015 with the support of the Global Environment Facility (GEF) and the United Nations Development Program (UNDP). The economic value of each individual ecosystem service of the SRP Koviljsko - petrovaradinski rit was made by the use of specific methodology, in order to obtain the most objective assessment. Field data are combined with literary and official data, but also with informal information, as needed (Provincial Institute for Nature Protection, 2015). Detailed economic assessment was performed for the following ecosystem services: cattle grazing; commercial fishing; groundwater; forestry; reed exploitation; air purification - forest ecosystems, water and vegetation as regulators; water purification; carbon-forest bonding; carbon sequestration - soil; flood mitigation; pollination; control of unwanted rodents by birds; control of undesirable rodents by carnivores; hunting tourism; recreational fishing; tourism; aesthetic values; habitat revitalization projects. The economic assessment showed that the highest value in this SRP is the ecosystem service is „flood mitigation" $(1,350,867,714.00$ dinars) while the lowest economic value of the ecosystem service is ,tourism" (38,000.00 dinars), which shows that the tourism utilization of the SRP is at a very low level. This also showed that the ecosystem service ,forestry”, which has traditionally been considered the most cost-effective value of the SRP, is far below the service of ,flood mitigation". The obtained financial indicators are especially important for making decisions on the management of SRP Koviljsko - Petrovaradinski rit, and in general for protected areas of Serbia.

Table 1. Ecosystem service in Special nature reserve Koviljsko-petrovaradinski rit

\begin{tabular}{|l|l|l|}
\hline Type of service & Subclass & Value (in RSD) \\
\hline \multirow{5}{*}{ Provisioning } & Grazing & $60.816 .700,00$ \\
\cline { 2 - 3 } & Commercial fishing & $31.501 .141,00$ \\
\cline { 2 - 3 } & Underground waters & $131.745 .076,00$ \\
\cline { 2 - 3 } & Forestry & $123.786 .642,00$ \\
\cline { 2 - 3 } Regulating & Reed exploitation & $240.000,00$ \\
\hline \multirow{5}{*}{ Cultural } & Air purification - forest ecosystems, water and vegetation as regulators & $74.990 .349,9$ \\
\cline { 2 - 3 } & Water purification & $397.800 .000,00$ \\
\cline { 2 - 3 } & Carbon sequestration- forests & $3.533 .934,00$ \\
\cline { 2 - 3 } & Carbon sequestration- soil & $129.422 .597,00$ \\
\cline { 2 - 3 } & Flood mitigation & $1.350 .867 .714,00$ \\
\cline { 2 - 3 } & Pollination & $43.015 .811,00$ \\
\cline { 2 - 3 } & Control of rodents by birds & $515.016,00$ \\
\cline { 2 - 3 } & Control of rodents by carnivores & $714.546,00$ \\
\hline \multirow{5}{*}{ Supporting } & Hunting tourism & $159.150,00$ \\
\cline { 2 - 3 } & Recreational fishing & $821.464,70$ \\
\cline { 2 - 3 } & Tourism & $38.000,00$ \\
\cline { 2 - 3 } & Esthetic value & $3.509 .356,00$ \\
\hline \multirow{2}{*}{ Total } & Habitat revitalization projects & $2.320 .778,00$ \\
\hline
\end{tabular}

Source: Pokrajinski zavod za zaštitu prirode (2015:53)

The analysis of stakeholders (individual, groups or organizations that are in any way interested in the implementation of a particular strategy) was focused on the relationship or impact on the protection of the SRP Koviljsko-Petrovaradinski rit. Thus, several groups of stakeholders which are inter- 
ested in the conservation of the area and can influence the implementation of conservation measures have been identified, including companies, institutions and other organized groups. These are land owners, managers, local users, state institutions, local self-government, media and NGOs. Part of the stakeholders was actively engaged and participated in the implementation of conservation measures, while other part was passively engaged, meaning that conservation has affected them.

The case study for Bosut forests covers four basic ecosystem services, which the subject area provides, namely: wood production, flood mitigation, food production (pork) and biodiversity. Flood safety, sustainability of income in forestry, nature conservation and well-being of the local population depend on the above four ecosystem services (Pokrajinski zavod za zaštitu prirode, 2018). As part of this assessment, two round tables were held with the participation of key sectors and users of the area in the field of forestry, water management, traditional livestock and nature protection, to recognize the needs of users and improve cooperation in the use and management of Bosut forests. The assessment aimed to show the possibility of increasing of benefits from ecosystems (quantitatively and qualitatively), by introducing integrated planning and multipurpose use of the area. The two basic recommendations derived from the Study are that Bosut forests should be used as forest retention on up to 10,000 ha and that the number of pigs in forests should be systematically increased to 5000-7000. Both of these changes should be implemented in a planned manner, with prior consultation with the main users (forestry, water management, traditional livestock and nature protection), as well as with other sectors (hunting, fishing, agriculture, infrastructure, etc.). In relation to tourism, the tourist offer of Bosut forests, which is poorly developed and related to the natural environment (hunting, fishing, traditional products and eco-tourism), could be significantly improved with an adequate strategy.

In 2019 the project EcoWet - Assessment of wetland ecosystem services in the cross-border area Croatia-Serbia was completed. The project aimed to contribute to the protection and sustainable use of wetland ecosystems and their services (Pokret Gorana Sremske Mitrovice, 2019). Wetland ecosystems have multiple significance for humans, from water purification, flood risk reduction, climate regulation to providing opportunities for various types of recreation. This was the key motive for the Nature Conservation Movement of Sremska Mitrovica, the Organization for Nature and Environmental Protection Zeleni Osijek, the Provincial Institute for Nature Protection and the Public Institution Agency for Management of Protected Natural Values in Osijek-Baranja County to launch the EcoWet project. The pilot areas where the research was conducted were: Bara Trskovača, Bosutske šume and SRP Zasavica (in Serbia); and nature reserve Podpanj, ponds Donji Miholjac, Northern Croatian Danube region and Spačva basin (in Croatia). Main outputs of the projects are: guidelines for the assessment of ecosystem services, a plan for the improvement of key services of wetland ecosystems in the project area, system for natural wastewater treatment at the visitor center of the Special Nature Reserve Zasavica and revitalized Ivovac canal in Zlatna Greda near Osijek.

\section{PROTECTED AREAS IN SERBIA WHERE THE PA-BAT METOD WAS APPLIED}

The assessment of the value of protected areas in Serbia using the PA-BAT methodology was conducted in six protected nature areas from different geographical parts of Serbia: Tara, Djerdap, Fruška gora and Kopaonik National Parks, Vlasina Landscape of Outstanding Features and Gornje Podunavlje Special Nature Reserve (Sekulic et al., 2018). The total area of protected areas in which the PA-BAT methodology has been applied is 160,000 ha, which is $35 \%$ of the total area of all protected areas in Serbia. 
Tara National Park is one of a total of five national parks in Serbia (next to Djerdap, Fruška gora, Kopaonik and Shar Mountain) which is protected by law (Zakon o nacionalnim parkovima, 2015-2018). It was first declared a national park in 1981, and is located in the western part of Serbia, on the border with Bosnia and Herzegovina. It covers parts of the territory of one municipality - Bajina Basta, in 10 cadastral municipalities, with a total area of 24,991.82 ha. This national park is managed by the Public Company „Tara National Park” from Bajina Basta. Tara National Park is part of the wider Tourist Region „Western Serbia” (Strategija razvoja turizma Republike Srbije za period od 2016. do 2025. godine, 2016). Djerdap National Park is located in the northeastern part of the Republic of Serbia, on the border with Romania. It was declared a national park in 1974 and is located on the territory of three municipalities (Golubac, Majdanpek and Kladovo), within 17 cadastral municipalities, total area 63,786.48 ha. This national park is managed by the Public Company „Djerdap National Park” from Donji Milanovac. The Djerdap National Park is part of the tourist destination „Donje Podunavlje” (Strategija razvoja turizma Republike Srbije za period od 2016. do 2025. godine, 2016).

Fruška gora National Park is located in the northern part of Serbia in the Autonomous Province of Vojvodina. It was declared a national park in 1960 and is located on the territory of eight municipalities (Novi Sad - Petrovaradin, Sremska Mitrovica, Backa Palanka, Beocin, Indjija, Irig, Sremski Karlovci and Sid) and 45 cadastral municipalities, total area 26.672 ha. This national park is managed by the Public Company „National Park Fruška gora” from Sremska Kamenica. Fruška gora National Park is part of the tourist destination „Novi Sad, Fruška gora and Sremski Karlovci" (Strategija razvoja turizma Republike Srbije za period od 2016. do 2025. godine, 2016). Kopaonik National Park is located in the southern part of Serbia. It was declared a national park in 1981, and is located on the territory of two municipalities (Raška and Brus), within 16 cadastral municipalities, with a total area of 11,969.04 ha. This national park is managed by the Public Company „Kopaonik National Park” with its headquarters on Kopaonik. The Kopaonik National Park is part of the tourist destination „Kopaonik” (Strategija razvoja turizma Republike Srbije za period od 2016. do 2025. godine, 2016).

The Landscape of exceptional features Vlasina is located in the southeastern part of Serbia. It was declared by the Government as a natural area of exceptional importance of the first category of protection (Decree on the proclamation of the Landscape of Exceptional Features of Vlasina, 2018), and it has been under protection since 2006. It is located on the territory of two municipalities (Surdulica and Crna Trava), in nine cadastral municipalities, with a total area of 13,329.84 ha. The landscape of exceptional features is managed by the Tourist Organization of the Municipality of Surdulica, from Surdulica. The area of exceptional features of Vlasina is part of the wider tourist destination „PIO Vlasina, Vranje and Vranjska Banja” (Strategija razvoja turizma Republike Srbije za period od 2016. do 2025. godine, 2016). The special nature reserve Gornje Podunavlje is located in the western part of Vojvodina. It was declared by the Government as a natural area of exceptional importance of the first category of protection (Decree on the protection of the Special Nature Reserve of the Upper Danube, 2001-2009), with a total area of 19605 ha and has been under protection since 2001. It covers the left bank of the Danube River from Bogojevo $(1367+500 \mathrm{~km})$ to the border with the Republic of Hungary $(1433$ $\mathrm{km})$. The special nature reserve is managed by the Public Company „Vojvodinašume” from Petrovaradin. The Special Nature Reserve of the Upper Danube is part of the tourist destination „Upper Danube with Bačka canals” (Strategija razvoja turizma Republike Srbije za period od 2016. do 2025. godine, 2016). 
Table 2. Assessed protected areas

\begin{tabular}{|l|c|c|c|l|}
\hline \multicolumn{1}{|c|}{ Protected Area } & Year of protection & Area (ha) & $\begin{array}{c}\text { IUCN* } \\
\text { management } \\
\text { category }\end{array}$ & \multicolumn{1}{|c|}{ Manager } \\
\hline $\begin{array}{l}\text { National Park } \\
\text { Fruška Gora }\end{array}$ & 1960 & 26672 & II & $\begin{array}{l}\text { Public Enterprise } \\
\text { NP Fruška gora }\end{array}$ \\
\hline $\begin{array}{l}\text { National Park } \\
\text { Đerdap }\end{array}$ & 1974 & 63786 & $\begin{array}{l}\text { II/UNESCO Global } \\
\text { Geopark }\end{array}$ & $\begin{array}{l}\text { Public Enterprise } \\
\text { NP Đerdap }\end{array}$ \\
\hline $\begin{array}{l}\text { National Park Tara } \\
\text { National Park } \\
\text { Kopaonik }\end{array}$ & 1981 & 24991 & II & $\begin{array}{l}\text { Public Enterprise } \\
\text { NP Tara }\end{array}$ \\
\hline $\begin{array}{l}\text { Landscape of } \\
\text { Exceptional } \\
\text { Features Vlasina }\end{array}$ & 1986 & 11969 & $\begin{array}{l}\text { Public Enterprise } \\
\text { NP Kopaonik }\end{array}$ \\
\hline $\begin{array}{l}\text { Special Nature } \\
\text { Reserve Gornje } \\
\text { podunavlje }\end{array}$ & 2006 & 13329 & $\begin{array}{l}\text { Toruism } \\
\text { Organization } \\
\text { Surdulica }\end{array}$ \\
\hline
\end{tabular}

* Categorization of protected areas in Serbia has not been harmonized with the IUCN categorization and the given categories are orientation only.

\section{PA-BAT METHODOLOGY}

The Protected Areas Benefit Assessment Tool (PA-BAT) is used to assess the value of protected nature areas, their potential and the benefits that protected areas provide to stakeholders. This methodology was developed to help gather information on a range of protected area values, as well as their current and potential benefits (economic and essential) of individual protected areas through a participatory approach (Dudley \& Stolton, 2009). The results of the PA-BAT analysis can be used on the state level as well as on the local or protected area level, to improve the management of these areas and to develop appropriate policies that support nature protection, while promoting sustainable development and responsible use of natural resources.

The implementation of the PA-BAT methodology includes the following steps: determination of the PA-BAT coordinator for each protected area; collecting basic data on the protected area; organizing participatory workshops in protected areas; conducting a survey among stakeholders; verification of the obtained data and their analysis for each protected area at the international and national level; preparation of guidelines for the application of the obtained results; and implementation of recommendations. This methodology identified eight groups of stakeholder beneficiaries, namely: local population living in the protected area; local population living in the vicinity of the protected area; total (national) population; scientists / experts; civil society organizations; public sector, state / protected area manager; business sector; and the international community. PA-BAT is based on a total of 22 values of protected areas (tourism and recreation, nature conservation, water quality and quantity, cultural and historical values, specific characteristics of the area, formal and non-formal education, knowledge building, fishing, hunting, commercial and non-commercial water use, wood, pollination and honey production, medicinal herbs, edible herbs and mushrooms, protected area activities, traditional agriculture, livestock grazing, natural materials, genetic materials, soil stabilization, climate change mitigation and flood mitigation). These 22 values of protected areas are classified into nine groups, namely: nature protection; protected area management; food; water; culture; health and recreation; knowledge; ecosystem services; and natural materials. 
The evaluation of the stated values is performed according to a scale that includes six levels, as follows: no profit (empty cell); small non-economic / existential profit $(+)$; large non-economic / existential gain $(++)$; small economic profit $(€)$; large economic gain $(€ €)$; and potential economic gain (P). Low economic / non-economic value essentially refers to small importance for a certain group of stakeholders, or that it is significant only for a narrow circle of stakeholders. High economic / non-economic value is important for a number of groups / stakeholders. In the analysis, PA-BAT combines stakeholder assessment at the workshop, information gathered by protected area managers and expert assessment in the data verification process. Valuable data are also obtained from surveys conducted with participants after each workshop. PA-BAT in Serbia was conducted in six protected areas by WWF Adria with the participation of more than 150 representatives of local communities, managers of protected areas, users of natural resources, government officials, entrepreneurs, experts and representatives of NGOs and other persons and institutions (Sekulic et al., 2018).

\section{RESULTS AND DISCUSSION}

\subsection{Economic and non-economic values and the main potentials of protected areas in Serbia}

Using the PA-BAT methodology, workshop participants assessed economic and non-economic / existential values in terms of the benefits that protected areas provide to a range of stakeholders and users. Of the 22 values offered, each was recognized by at least one stakeholder group. The values that are most recognized are tourism and recreation, natural resources and biodiversity, cultural and historical values, water quality and quantity, forests / forestry, wild edible plants and mushrooms. These six values account for $48 \%$ of the total number of responses provided by all stakeholders (Sekulić et al, 2018).

Stakeholders belonging to the local community group most easily connect tourism as an economic activity with protected areas, while the natural and cultural values of the protected area are connected with tourist destinations that support the local economy by providing various services. Nature protection is recognized as a basic function of protected areas by different stakeholder groups. This data shows that stakeholders support protected areas and that their management meets the primary objectives, when it comes to the six analyzed protected areas in Serbia. Water resources, in terms of quantity and quality, are highly dependent on the preservation of ecosystems. This was recognized by the communities that live in rural areas and are in constant contact with nature. The high positioning of the values of protected areas related to water resources in the assessed areas reflects the strong dependence of people, water and preserved ecosystems. Cultural and historical values are closely related to the protected areas in Serbia. Many protected areas have a very rich cultural history as well as numerous cultural monuments and facilities. Most of the protected areas have been inhabited since ancient times, although today in most of those areas there is an evident depopulation trend. Cultural heritage stands out not only because of its potential for attracting tourists, but also because of the spiritual values it has for the local population and community (Dobričić \& Josimović, 2018). In addition to the above, more and more attention is being paid to an integrative approach in which natural and cultural heritage are interconnected, which, among other things, requires a vital connection with communities (Velandia \& Ospina-Tascón, 2020).

The current management in most protected areas allows forest exploitation. Managers of protected areas (except in the case of the Landscape of Outstanding Features of Vlasina, which is managed by 
a tourist organization), very much depend on activities related to forestry, because it contributes significantly to their budget. Many stakeholders recognize wood production as one of the main values of protected areas. The local community uses wood for its own needs (mainly as fuel), but also participates in the sale of wood assortments. Other values related to various ecosystem services such as hunting, fishing, wild edible herbs and mushrooms, medicinal herbs, honey production are also highly recognized in the assessment. Very relevant for protected area managers is the fact that the participants recognized the value of protected areas in education and knowledge development. Social values and benefits are very often underestimated and neglected in the process of protected area management. These results show that it is necessary to encourage and direct managers and users of protected areas towards protected area management concepts based on an integrated approach.

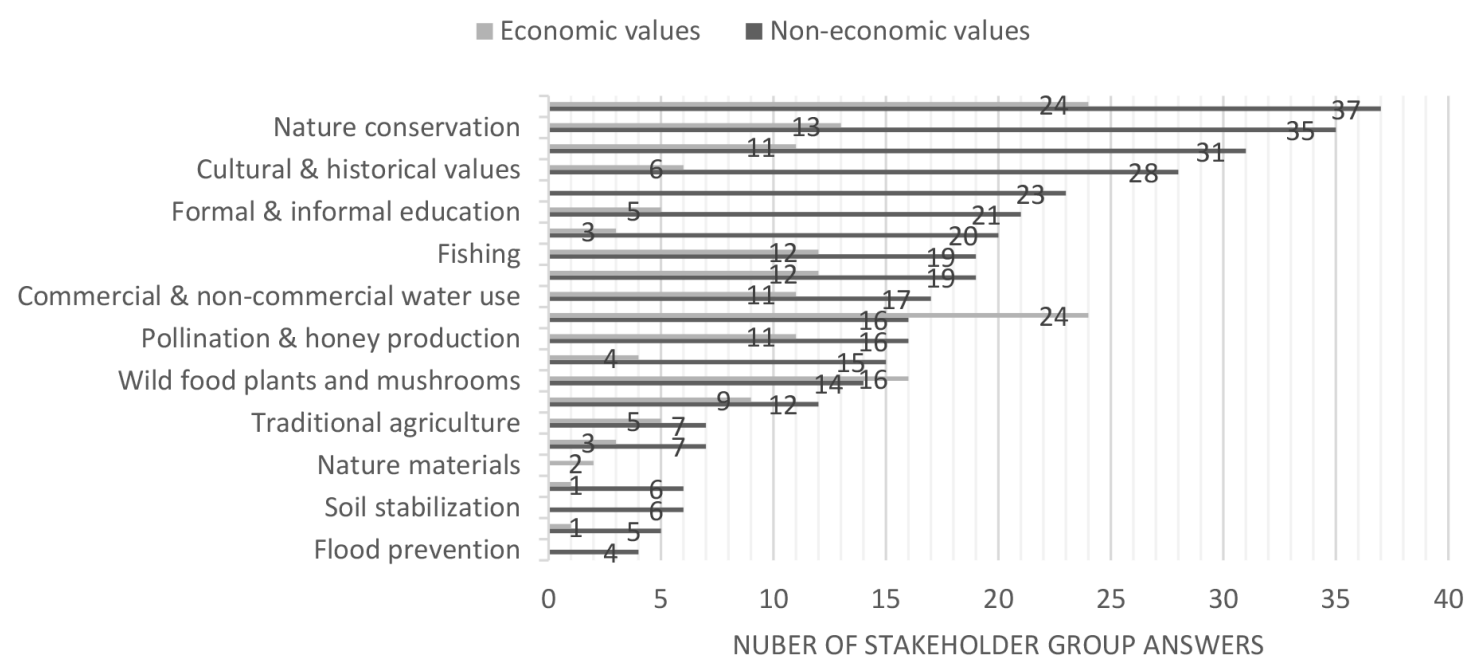

Figure 1. Economic and non/economic values and benefits of analyzed protected areas in Serbia (PA-BAT results).

Source: Sekulić et al.,2018

The importance of protected areas for generating new jobs is not so much emphasized in the assessment. Stakeholders generally recognized the possibility of employment in an organization that manages a protected area, but not so much other jobs that may be related to the protected area or the values it has (e.g. jobs in tourism, trade in natural and local products, etc.). Agricultural production in the protected area is not recognized as a relevant value and a relatively small number of stakeholders currently benefit from it. Rural and mountainous areas with the largest number of assessed protected areas are very affected by negative trends in agricultural production, but also by the migration of the population to larger, mostly urban areas. In new approaches to protected area management, traditional and sustainable agriculture is perceived as an important segment of the conservation of natural habitats and species (e.g. grazing as a way of managing mountain pastures). Obviously, such management practices have not yet been adequately developed in Serbia. The least recognized values are related to regulatory and supportive ecosystem services, such as climate change mitigation, land stabilization and flood mitigation. Public awareness of these important services of an ecosystem is very low. Ecosystem services represent a new concept and it will certainly take some time to be accepted and adequately valued by the local community. Specific knowledge related to local erosion and flood characteristics, droughts and landslides exists, but it is not considered in the broader context of access to ecosystems and climate change.

In addition to assessing the economic and non-economic value of protected areas, an overview of the main potentials of protected areas identified by different stakeholder groups also provides 
very important information to protected area managers and decision makers. As can be seen in Figure 2, tourism is at the very top of the recognized potentials, as one of the most important values of a protected area that can bring significant benefits to various stakeholders, especially to those living in economically vulnerable areas, such as mountain areas (Pantić \& Milijić, 2019). However, protected area managers need to adapt their knowledge and capacity to new requirements in order to improve the management of these areas. Education is very high on the list of potentials. A high position of value that does not have an explicit economic impact is contrary to the current concept of protected area management, which largely relies on the direct use of resources. This statement shows that stakeholders are ready for more advanced, integrated management of protected areas that can benefit a wider group of actors. The stated assumption is supported by a very low assessment of the potential for forest use, which is the current basic characteristic of the management method in most protected areas in Serbia.

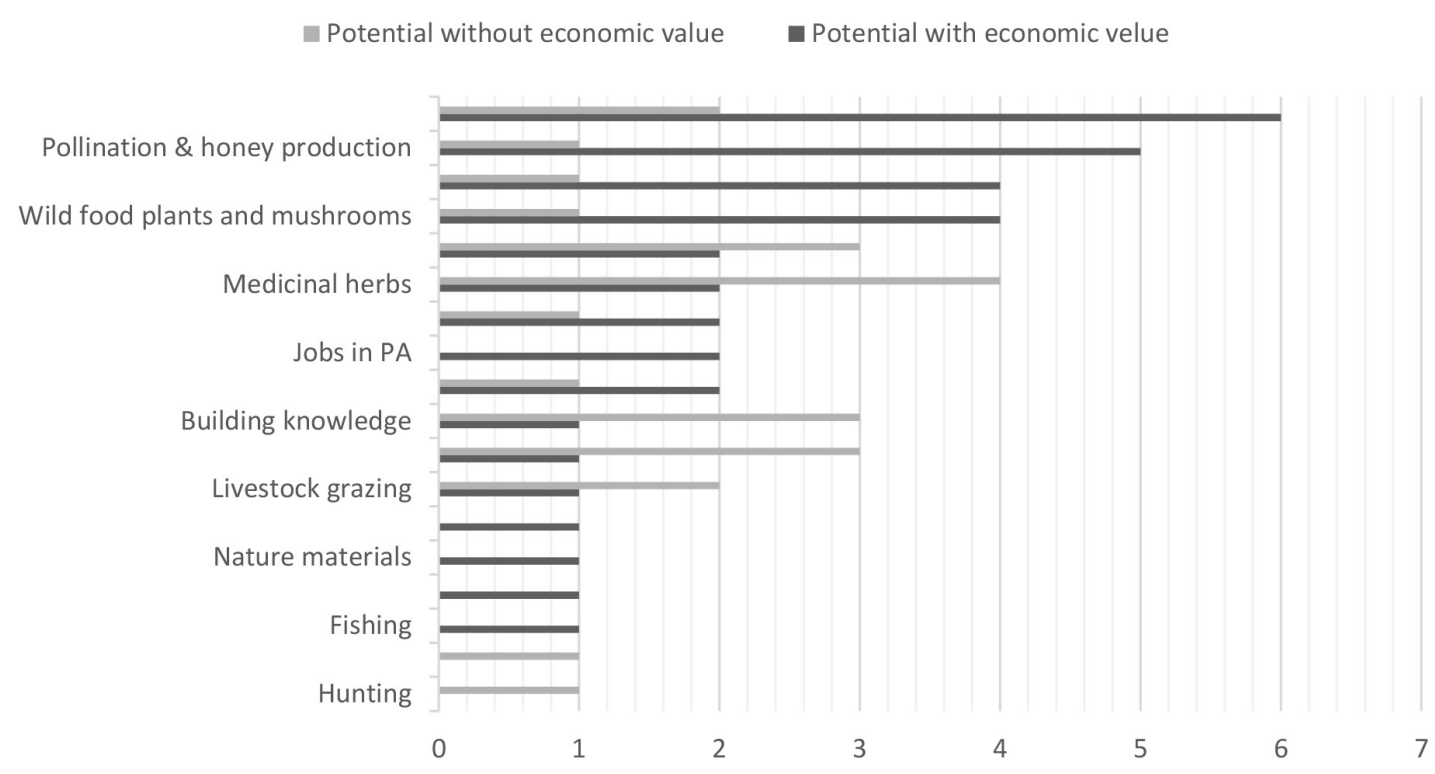

Figure 2. Main potentials of protected areas in Serbia (PA-BAT results)

Source: Sekulić et al., 2018

The need for participatory governance that is open to local communities and other stakeholder groups is also reflected in the recognition of potential in the collection of wild edible plants and mushrooms as well as in honey production. These activities are mainly carried out by the local population in the protected areas and in their surroundings, but they do not have adequate support from the managers. Traditional agriculture and cattle grazing are not highly rated among the potentials. Current market developments and agricultural policies, however, recognize great potential in areas with preserved natural resources, especially in the production of healthy and organic food. These potentials should not be overlooked and therefore further consideration by protected area managers and other stakeholders is needed.

\subsection{Economic assessment of tourism and other values of protected areas in Serbia}

An assessment based on the PA-BAT methodology showed that stakeholders in all six protected areas recognize the non-economic value of tourism. In the national parks of Tara and Kopaonik and in the area of exceptional features of Vlasina, interested groups consider tourism in a protected area as the greatest economic value for them. The values related to tourism and recreation were almost equally recognized by all stakeholder groups. They were better recognized by the public 
sector, entrepreneurs and the general public (15\% of the total number of responses), while the local community living in the protected area recognizes these valuessomewhat less $(8 \%$ of the total number of responses). Based on the obtained results, it can be assumed that the local community living in the protected area is not adequately integrated in the planning of tourism activities.

A good example of the integration of the local community into tourism is Bački Monoštor, a village located next to Gornje Podunavlje Special Nature Reserve and within the boundaries of the UNESCO-MAB Bačko Podunavlje Biosphere Reserve. The community is well organized when it comes to local accommodation, local food and craft products and all services are based on small entrepreneurs. Two well-attended and popular festivals are organized every year, such as „Bodrog Fest” and the eco-music festival „Danube Regeneration”. This example gives hope that other protected areas in Serbia will follow a similar path.

Protected areas, especially those of national and international importance are a special attraction for the development of tourism products. Their preservation and further protection and improvement of the sustainable management system is an important condition for increasing tourism traffic (Strategija razvoja turizma Republike Srbije za period od 2016. do 2025. godine, 2016). If not adequately planned and organized, tourism can become a major threat to protected areas and their values. Therefore, it is necessary to adequately consider and resolve potential conflicts (Dobricic \& Maksic, 2017) between the development of tourism (and other purposes in space) and nature protection, in order to avoid harmful impact on the values of natural resources and life of local communities. In addition, it is necessary to conduct planned tourism valorization of such areas, as well as to monitor the impact of tourism on the protected areas. One of the effective mechanisms for achieving sustainable tourism in protected areas is the European Charter for Sustainable Tourism, developed and supported by the EUROPARC Federation. Fruška gora National Park and Gornje Podunavlje Special Nature Reserve are the first protected areas in Serbia to receive the charter.

A good example of the development of tourism in protected areas is the development of a specific tourism offer - bear watching in the Tara National Park, which was implemented as a component of a regional project „Protected areas for nature and people” which is implemented by WWF Adria and Association of Parks Dinarides. This project aims to improve the protection and conservation of wild species and their habitats, through specific field activities and cooperation with national parks and local people. Cooperation with hunters and the local community in the development of a specific tourist offer - bear watching and accompanying tourist services and products, should contribute to the creation of coexistence between humans, wild species and protected nature.

In addition to tourism, stakeholders have recognized other values of protected areas such as forestry. Forestry is recognized by most stakeholder groups as the greatest economic value. Wood, as a natural resource, is most recognized by the local community living in the protected area or in its immediate vicinity (50\% of all responses). This is followed by government representatives and business sector representatives (approximately 30\% of all responses), while the total population and civil society organizations represent groups that do not recognize wood as a significant value (less than $10 \%$ of all responses). Stakeholders have shown that the values of protected areas associated with water resources have a clear economic significance for them. The economic value of water resources is mostly recognized by the public and private sectors, primarily through hydropower, water bottling companies and factories and communal water supply systems, while the local community living within or near protected areas generally recognizes the non-economic value of water - used to supply the population. 


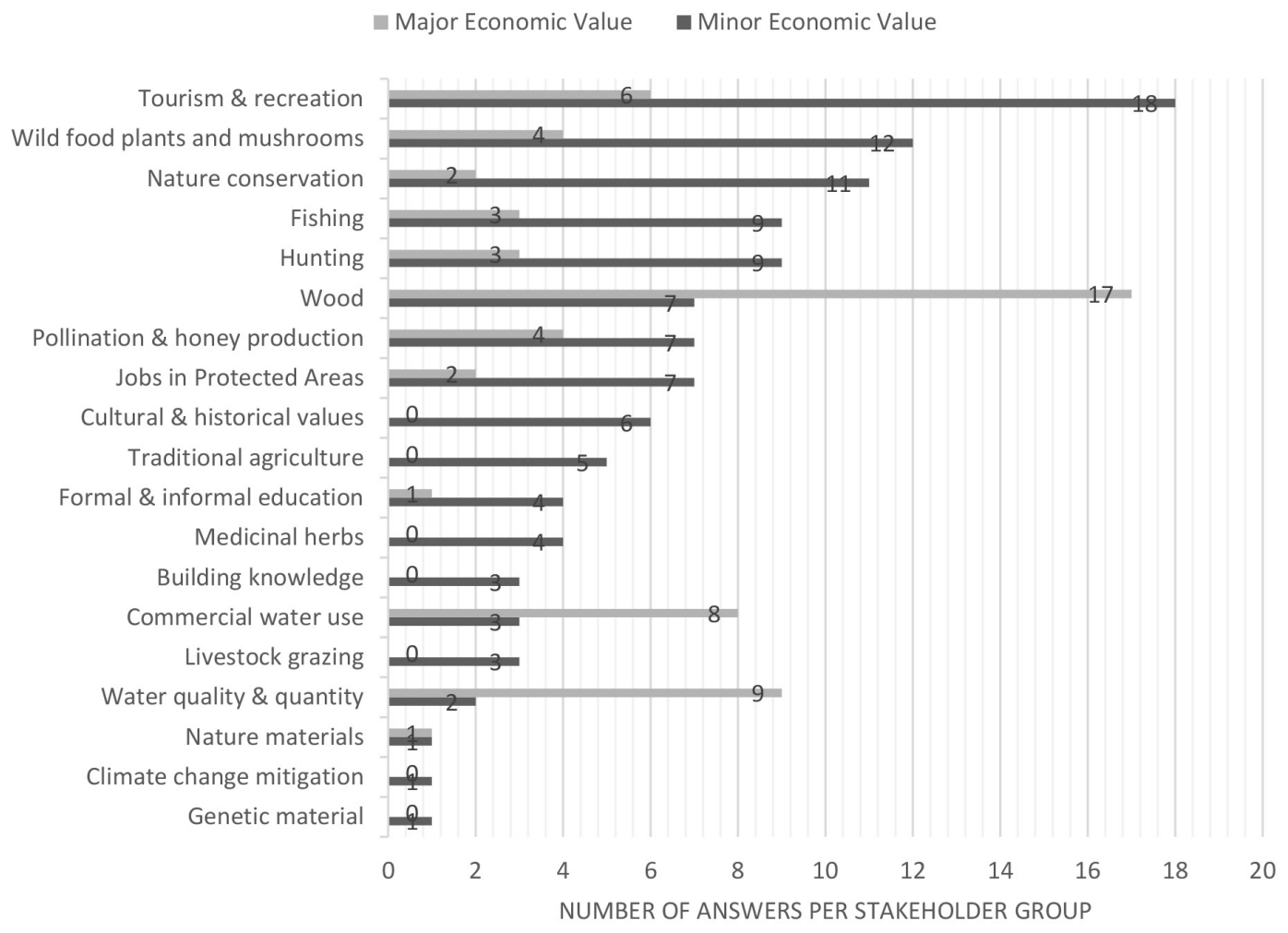

Figure 3. Minor and major economic value of protected areas (PA-BAT results)

Source: Sekulić et al., 2018

In five of the six protected areas assessed, stakeholders recognized the economic value of collecting wild edible plants and fungi. Obviously, wild fruit collection is a significant source of income for local communities. The interested group most involved in the collection of wild edible plants, medicinal herbs and mushrooms are people living in the vicinity of protected areas (about $40 \%$ of the total responses). According to the number of responses, they are followed by the community living in the protected area itself, which recognized the value of wild fruits and plants with about $20 \%$ of the total responses. The value of honey production was recognized by all stakeholders in all assessed protected areas. A very popular destination for honey production is the Fruška Gora National Park, due to the large population of linden trees in that national park, which is very attractive for beekeepers. To some extent, it is surprising that stakeholder groups rated education relatively high relative to all other values of protected areas. In three protected areas, education was recognized as a low economic value, but in all six areas it was recognized as a non-economic value. Observed according to the total number of answers, education is in the first third of the highest rated non-economic values. Recognition of the value of education is evenly distributed among different stakeholder groups. There is no significant difference in how the importance of education is seen by the local community living in the protected area, the administration of the protected area, representatives of the public or business sector. Some of the protected areas are also traditional destinations for school excursions, primarily the Tara and Djerdap National Parks.

\subsection{The importance of public participation in the management of protected areas and application of the results obtained by PA-BAT assessment}

The results obtained by the PA-BAT assessment confirm the fact that the concepts of protected area management rely on intensive cooperation of different stakeholders. Therefore, protected area administrations should not only inform stakeholders about their work but should develop 
opportunities to involve them in planning and management. Participation significantly increases the effectiveness of protected area management, but also provides a favorable environment for the development of sustainable ways of using natural resources and thus reduces the negative impacts on protected areas (Sekulić et al, 2018). Most of the protected areas assessed in Serbia were established by the government sector with very low participation of other stakeholder groups, especially the local community. Gradually, this practice has changed over the last two decades. The value of involving different stakeholders has not yet been fully recognized and accepted, but some change in practice is visible. The legal framework has also undergone positive changes. National parks have been obliged to establish a national park user council since 2015 (Zakon o nacionalnim parkovima, 2015-2018). Certain legal provisions on participation in the process of establishing of a protected area and in adopting management plans exist, although they are not sufficiently specific and clear.

The research showed that the majority of users (more than 50\%) support the open discussion about the values and benefits of protected areas, and that they are interested in gaining more information and knowledge on this topic. The obtained results indicate that a certain level of communication between different stakeholders exists, but that it should be further improved. About $80 \%$ of participants showed interest in establishing future cooperation with other stakeholder groups, which may be important in the development of new local initiatives, cooperation and joint projects in the future. These results as well show the importance of the PA-BAT process for stakeholders. The described assessments are not exclusively technical processes used to assess the value and well-being of protected areas, they are also a mechanism for achieving good communication and cooperation between different actors in protected areas.

Possibilities of applying the results obtained by PA-BAT analysis include the following strategic recommendations for improving the system of protected areas in Serbia: (1) integrating the value of protected areas into sectoral strategies and plans, tourism, forestry, water resources, spatial planning, energy, education, etc.); (2) abandoning a model in which protected areas rely solely on the exploitation of natural resources; (3) supporting activities based on values with high recognized potential (e.g. tourism, education, collection of wild edible plants) through legal framework, planning processes and financial mechanisms.

General recommendations at the level of protected areas include: (1) integrating identified values and benefits into protected area management plans; (2) informing decision makers about the values and benefits of protected areas and advocating for the integration of protected area issues into strategic documents of other sectors (e.g. forestry, water management, spatial planning, energy); (3) formation of groups of stakeholders whose work will be focused on individual activities (focus groups); (4) transformation of current protected area management mechanisms, to enable the integration of local, sustainable initiatives; (5) capacity development in accordance with the identified values and their potentials; (6) improving the monitoring of biodiversity and identified values, as well as monitoring and control in relation to the values assessed in the PABAT analysis; (7) increasing tourist capacities and improving the tourist offer by developing partnerships with local actors in tourism; Bearing in mind that protected areas are part of tourist destinations in Serbia, the increase of tourist capacities and the improvement of the tourist offer is possible only within the limits of sustainable tourism; (8) developing specific educational programs in protected areas and developing partnerships with schools and academic institutions; (9) conducting a detailed analysis of the condition and quantities of wild edible plants, mushrooms and medicinal plants; market development based on the principles of fair trade for wild 
fruits, plants and mushrooms in or around protected areas; (10) identifying and connecting with vulnerable stakeholders (e.g. poor population, women in rural areas, etc.), and involving them in sustainable economic activities of protected areas.

\section{FUTURE RESEARCH DIRECTIONS}

This chapter provides only a limited set of general recommendations for improving the system of protected areas in Serbia. Each protected area is specific, and as such requires additional analysis of potentials, challenges and possible solutions. Therefore, it is necessary to integrate the identified values and benefits into the protected area management plans and, if necessary, perform a review of protected area management plans in relation to the results of the PA-BAT analysis. It is recommended that the PA-BAT value analysis should be periodically repeated in order to update the obtained values and prepare new cycles of protected area management plans. Existing analysis include only limited number of protected areas, therefore it is necessary to perform the analysis in other protected areas of Serbia, especially those that are under national and international protection (such as Nature Park and Golija Biosphere Reserve, Special Nature Reserve and Ramsar site Obedska bara, etc.). Further research should be based on the possibilities of applying the results of PA-BAT in other sectors, such as tourism, spatial planning, etc.

\section{CONCLUSION}

A comprehensive assessment and evaluation of the value and benefits of protected areas is a contribution to achieving a more efficient system of protected areas and nature protection in Serbia. Examples of ecosystem services assessments conducted in Serbia so far, such as assessments of the value of special nature reserves in Koviljsko-Petrovaradinski rit and Zasavica, Bosutske šume or Djerdap National Park, also contributed to the study and better management of protected areas. The assessment with the PA-BAT methodology, which was done in six protected areas in Serbia (national parks Tara, Djerdap, Fruška gora and Kopaonik, Landscape of exceptional features of Vlasina and the Special Nature Reserve of the Upper Danube), showed that stakeholders recognize a wide range of values and benefits which they offer. Stakeholders have identified many values that are important to them from an economic and non-economic perspective. Among these values are not only values that rely on traditional and direct use of natural resources, such as e.g. forestry and mining, but also values based on sustainable practices that depend strongly on the protection and conservation of natural resources, such as tourism and recreation or education. In addition to the analyzed six protected areas in Serbia, it is necessary to further apply PA-BAT in other protected areas of Serbia, especially those under national and international protection, all in order to obtain a comprehensive picture of protected areas in Serbia and generally improve nature conservation.

The development of tourism in protected areas is directly related to the ecosystem services they provide; the degradation can directly affect the ecological sustainability of the tourism sector. Therefore, the development of tourism requires careful and planned valorization of these areas. The obtained results of the PA-BAT analysis indicate the need for further development of the network of protected areas and improvement of the management of existing protected areas. The PA-BAT methodology supports these processes systematically and transparently. In addition to identifying values, this method contributes to initiating and developing communication and cooperation between different users and stakeholders (through the establishment of a national park user council, focus groups of stakeholders whose work would be focused on individual activities, etc.), which is a fundamental need for more efficient management of protected areas in Serbia. 


\section{REFERENCES}

Costanza, R., d'Arge, R., de Groot, R., Farber, S., Grasso, M., Hannon, B., Limburg, K., Naeem, S., O’Neill, R.V., Paruelo, J., Raskin, R.G., Sutton, P., \& van den Belt, M. (1997). The value of the world's ecosystem services and natural capital. Nature, 387, 253-260. https://doi. org $/ 10.1038 / 387253 \mathrm{a} 0$

Dobričić, M. (2012). Planska zaštita i održivi razvoj međunarodno zaštićene prirodne i kulturne baštine u Srbiji - razvoj metodologije planiranja i programiranja razvoja. Geografski fakultet, Univerziteta u Beogradu, doktorska disertacija.

Dobričić, M. (2012a). Zaštićena područja kao podrška očuvanju usluga ekosistema. U Stojkov, B., \& Dobričić, M. (urednici), Prostorno planiranje u Srbiji, aktuelne teme (str. 21-30). Republička agencija za prostorno planiranje, Beograd.

Dobričić, M., \& Josimović, B. (2018). Sinergija prirodnog i kulturnog nasleđa. Arhitektura i urbanizam, 46, 39-45. doi: 10.5937/a-u0-16268

Dobričić, M., \& Maksić, M. (2017). Relativization of conflicting interests between the development of transport and transport infrastructure and nature protection. ARTTE, 5(4), 250-256. doi: 10.15547/artte.2017.04.002

Dobričić, M., Sekulić, N., \& Josimović, B. (2017). Spatial planning and ecological networks in Serbia. SPATIUM, 38, 18-26. doi: https://doi.org/10.2298/SPAT1738018D

Dudley, N., \& Stolton, S. (2009). The Protected Areas Benefits Assessment Tool: A methodology. Gland, Switzerland: WWF.

Emerton, L. (2009). Economic valuation of protected areas: Options for Macedonia. Skopje. FYR Macedonia: UNDP-GEF/ Ministry of Environment and Physical Planning, Republic of Macedonia.

Flores, M., \& Ivicic, I. (2011). Valuation of the contribution of the ecosystems of Northern Velebit National Park and Velebit Nature Park to economic growth and human wellbeing. Croatia: WWF.

Flores, M., \& Selimi, E. (2013). The economic contribution of ecosystems in and around Sharr Mountains National Park to the economy in Kosovo. UNDP.

Gbadegesin A., \& Ayileka O. (2000). Avoiding the mistakes of the past: towards a community oriented management strategy for the proposed National Park in Abuja-Nigeria. Land Use Policy, 17(2), 89-100.

Ivanic Zorica, K. (2017). Applicability of Results from the Protected Area Benefit Assessment Tool (PA-BAT) to Protected Area Management in Croatia - The Example of Paklenica National Park. WWF Adria.

Ivanic Zorica, K., Štefan, A., Porej, D. \& Stolton, S. (2017). Using a participatory assessment of ecosystem services in the Dinaric Arc of Europe to support protected area management. Parks, 23.

Javno preduzeće „Nacionalni park Djerdap” \& Zavod za zaštitu prirode Srbije. (2014). Koristi ekosistemskih usluga NP Djerdap za lokalne zajednice. Srbija.

Lakićević, M. (2013). Primena Analitičkog hijerarhijskog procesa (AHP) i participativnog odlučivanja u upravljanju Nacionalnim parkom „Fruška gora”. Univerzitet u Beogradu, doktorska disertacija.

Millennium Ecosystem Assessment. (2005). Ecosystems and Human Well-Being: Synthesis. Island Press, Washington, DC.

Pantic, M., \& Milijic, S. (2019). Relations between Mountain Tourism, Demographic Structure and Employment at Local Level in Serbia. In Cvijanović et al (eds), Thematic proceedings I, The Fourth International Scientific Conference: Tourism in Function of Development of the Republic of Serbia, Tourism as a Generator of Employment, TISC 2019 (pp.148-164). University of Kragujevac, Faculty of Hotel Management and Tourism in Vrnjačka Banja. 
Pokrajinski zavod za zaštitu prirode. (2015). Ekonomsko vrednovanje ekosistemskih usluga Specijalnog rezervata prirode „Koviljsko - petrovaradinski rit“. Novi Sad, Srbija.

Pokrajinski zavod za zaštitu prirode. (2018). Studija slučaja: Predstavljanje ekosistemskih usluga sa valorizacijom na području Bosutskih šuma - integracija biodiverziteta i ekosistemskih usluga u korišćenje i upravljanje prirodnim resursima. Novi Sad. Srbija.

Pokret Gorana Sremske Mitrovice. (2019). Akcioni plan za unaređenje ekosistemskih usluga. Srbija.

Pueyo-Ros, J. (2018). The Role of Tourism in the Ecosystem Services Framework. Land, 7 (111). doi:10.3390/land7030111

Rastogi A., Badola R., Hussain S.A., \& Hickey G.M. (2010). Assessing the utility of stakeholder analysis to protected areas management: the case of Corbett National Park, India. Biological Conservation, 143(12), 2956-2964. doi: 10.1016/j.biocon.2010.04.039

Secretariat of the Convention on Biological Diversity (2010) COP-10 Decision X/2. Secretariat of the Convention on Biological Diversity, Nagoya. Retrieved from https://www.cbd.int/doc/decisions/cop-10/cop-10-dec-02-en.pdf

Sekulić, G., Ivanić Zorica, K., Porej, D. (2017). Protected Areas Benefit Assessment (PA-BAT) in Montenegro, WWF Adria.

Sekulić, G., Ivanić Zorica, K., Štefan, A. (2018). Protected Area Benefit Assessment Tool (PA-BAT) in Serbia. Belgrade: World Organization for Nature, Zagreb: WWF Adria.

Simmons, D.G. (2013). Tourism and ecosystem services in New Zealand. In Dymond JR (ed), Ecosystem services in New Zealand - conditions and trends (pp.343-348). Manaaki Whenua Press, Lincoln, New Zealand.

Spurgeon, J., Marchesi, N., Mesic, Z., \& Thomas, L. (2009). Sustainable Financing Review for Croatia Protected Areas. London, UK: Environmental Resources Management.

Strategija razvoja turizma Republike Srbije za period od 2016. do 2025. godine (,Službeni glasnik RS", broj 98/16).

Stojkov, B., \& Dobričić, M. (2012). Eco-services and the role of functional regions in Serbia. EUROPA XXI, 22, 149-161. doi: 10.7163/Eu21.2012.22.12

UN. (2015). Transforming our world: the 2030 Agenda for Sustainable Development. United Nations.

UNDP. (2011). The economic value of protected areas in Montenegro. Podgorica, Montenegro: UNDP, GEF and ISSP.

UNEP. (2016). Economic Transferability Study from Plitvice Lakes in Croatia to Una National Park in Bosnia and Hercegovina. Sarajevo, Bosnia and Herzegovina: UNEP.

Uredba o proglašenju Predela izuzetnih odlika Vlasina („Službeni glasnik RS”, broj 25/18).

Uredba o zaštiti Specijalnog rezervata prirode Gornje Podunavlje (,Službeni glasnik RS”, br. 45/01, 81/08 i 107/09).

Velandia, S.C.A., \& Ospina-Tascón, J.J. (2020). Intercultural landscapes: towards an interpretation. EdA Esempi di Architettura, 1 (1-2020). Retrieved from http://www.esempidiarchitettura.it/ sito/journal_pdf/PDF\%202020/5.\%20EDA_2020_VELANDIA_OSPINA.pdf

Woodruff, S.C., \& Ben Dor, T.K. (2016). Ecosystem services in urban planning: comparative paradigms and guidelines for high quality plans. Landscape and Urban Planning, 152, 90-100. http://dx.doi.org/10.1016/j.landurbplan.2016.04.003

WWF. (2011). Ecosystem Services Evaluation in the Škocjan Caves Regional Park. Rome, Italy: WWF.

Zakon o nacionalnim parkovima („,Službeni glasnik RS”, br. 84/15 i 95/18 - dr. zakon).

Zingstra H.L., Seffer, J., Lasak, R., Guttova, A., Baltzer, M., Bouwma, I., Walters, L.J., Smith, B., Kitnaes, K., Predoiu, G. E., Prots, B. \& Sekulic. G. (2009). Towards and Ecological Network for the Carpathians. Wageningen International, PO Box 88, 6700 AN Wageningen, Netherlands. 
